\title{
2 Diaspora/Film im Wandel
}

Whether ,diaspora' is a common word, a scientifically constructed concept, or a rallying cry that gives meaning to a collective reality, it is highly contemporary. Denying this would be pointless. (Dufoix, Diasporas 106)

In diesem Kapitel möchte ich mein Verständnis von Diaspora sowie von Diasporafilm erläutern. Dem zugrunde liegt die Annahme, dass beide Begriffe in stetigem Wandel begriffen sind und so der Prozesshaftigkeit, die sie beschreiben, selber unterliegen. Dies führt zu einer Aufweichung der Kategorien, die für eine filmwissenschaftliche Perspektivierung produktiv gemacht werden kann: Sowohl Diaspora als auch Diasporafilm stellen mehr als reine Beschreibungsgrößen dar, denn sie führen immer auch schon eine mediale und räumliche Dimension mit, die zu einer kulturellen Verortung der iranischen Diaspora beitragen sowie filmische Prozesse offenlegen.

Anhand einer Diskussion des Begriffes „Diaspora“ werde ich im Folgenden in einem ersten Schritt einen Überblick darüber geben, wie sich der Begriff von einer enggefassten Definition zu einer erweiterten Bezeichnung hin gewandelt hat. Dies ermöglicht mir in einem zweiten Schritt, Diaspora als Medienraum zu konzipieren. Ich tue dies, indem ich auf verwandte medien- und filmtheoretische Ansätze zu „Diasporamedien“ und „Diasporafilm“ Bezug nehme, dabei jedoch erstens aufzeige, wie sich der „Medienraum Diaspora“ dagegen abgrenzt, und zweitens für eine Aktualisierung und Öffnung der Kategorie der Diaspora und des Diasporafilmes plädiere. 


\subsection{Von der „Zerstreuung“ zu den Diaspora Studies}

Der Begriff „Diaspora“ stammt von dem altgriechischen Wort diasporá ab und bedeutet „Zerstreuung“.${ }^{17}$ Es handelt sich also in einer ersten Instanz um Menschen in Bewegung, die sich im weitesten Sinne räumlich zerstreuen. Der Soziologe Khachig Tölölyan, der Herausgeber des wissenschaftlichen Journals Diaspora: A Journal of Transnational Studies, macht dabei folgende Unterscheidung: „Dispersion“ is the more general and inclusive term, whereas ,diaspora“ is merely one of several kinds of dispersion so that, in a curious reversal, it has become a synecdoche, the part - diaspora - standing for the whole“ (5). Das Begriffspaar dispersion/diaspora dient ihm zu einer ersten Eingrenzung: Zerstreuung meinte einen allgemeinen Zustand menschlicher Mobilität und Migration, Diaspora beschreibt hingegen eine Subkategorie davon. Seine Begriffsbestimmung lautet daher: „In my view, diasporas are a special category of ethnicized dispersion“ (Tölölyan 7). Tölölyan argumentiert weiter, dass sich dieses Verhältnis umgekehrt habe und Diaspora nun als Begriff nicht mehr für das Partikulare, sondern für das Allgemeine stünde.

Eine erste Definition des Begriffes geschah im dritten Jahrhundert vor Christus im Zuge der Übersetzung hebräischer Schriften ins Griechische. In diesen Schriften wird der Begriff der Diaspora erstmals mit Bezug auf die Lebenssituation der Juden gebraucht (Mayer 8). Bis in die 1930er Jahre bezeichnete der Begriff hauptsächlich die Ausnahmesituation des jüdischen und später auch des armenischen Volkes. Ihre Zerstreuung war im Laufe der Jahrhunderte erzwungen und daher der Begriff Diaspora über lange Zeit laut Matthias Krings „ausschließlich negativ konnotiert“ (137). Der Soziologe Robin Cohen nennt diese Art der Diaspora „victim diasporas“ (x), im Gegensatz zu anderen Formen, 
die er 2006 in seiner Monographie Global Diasporas: An Introduction wie folgt in ,imperial diaspora“, ,labour diaspora“ und „cultural diaspora“ unterteilt:
Africans and Armenians are shown to be analogous victim diasporas. The British have been represented as an imperial diaspora, the Indians as a labour diaspora, while the trading diasporas have been typified by the Chinese and Lebanese. Finally, the peoples of the Caribbean abroad are, I suggest, usefully characterized as a cultural diaspora. (x)

Der Begriff Diaspora bekommt durch diese Einteilung einen erweiterten Bedeutungshorizont, meint er nun nicht mehr die bloße, von seiner etymologischen Bedeutung her geprägte „Zerstreuung“, sondern vielmehr unterschiedliche Kategorien historischer, ökonomischer, politischer und kultureller Migrations- und Bewegungsströme. Diese vorgeschlagenen Kategorien sind laut Robin Cohen nicht statisch, Gruppen lassen sich durchaus in mehrere Formen von Diaspora zugleich einordnen, beziehungsweise die Kategorien sind durch historische Prozesse, die sich im Laufe der Zeit ergeben, auch veränderbar. Vermehrt globale Entwicklungen bezeichnend, erfuhr der Begriff in den wissenschaftlichen Diskursen des neuen Jahrtausends eine noch nie dagewesene Konjunktur. Khachig Tölölyan führt diese Entwicklung auf vier historische Ereignisse zurück, die seiner Meinung nach zum gesteigerten Interesse für den Begriff im USamerikanischen Diskurs geführt haben: Als Erstes führt er die Bürgerrechtsbewegung der Vereinigten Staaten in den Jahren 1964/65 an, die die Umbenennung der „schwarzen“ beziehungsweise „,farbigen“ Bevölkerung in african diaspora und african-americans zur Folge hatte. Für den akademischen Diskurs ist hierbei Paul Gilroys The Black Atlantic als einschlägigstes Werk zu nennen. Als zweites Ereignis führt Tölölyan den Sechstagekrieg von 1967 zwischen Israel auf der einen und Ägypten, Jordanien und Syrien auf der anderen Seite an, der zu einer 
„Re-diasporisierung“ (6) verschiedener ethnischer, bereits in den Vereinigten Staaten lebender Gruppierungen beitrug. Es fühlten sich nunmehr auch Ir_innen, Italiener_innen, Griech_innen, Inder_innen et cetera bestärkt, ihre Lebenssituation neu zu verhandeln und als Diaspora zu bezeichnen. ${ }^{18}$ Als drittes Ereignis bezeichnet Tölölyan den Hart-Celler Immigration and Nationality Act, der 1965 vom amerikanischen Kongress verabschiedet wurde und eine Erhöhung der Quote für Immigrant_innen vorsah. Die Vereinigten Staaten wurden dadurch zu einem der größten Einwanderungsländer. Der vierte Grund ergibt sich aus den drei eben genannten und betont als Folge der historischen Ereignisse eine verstärkte Aufmerksamkeit für Identität, Differenz und Diversität im akademischen Diskurs (Tölölyan 6-8). Hier prägten im angelsächsischen Raum vor allem die postkolonialen Studien und Wissenschaftler wie der Soziologe Stuart Hall mit seinen Neuorientierungen der Konzepte von Ethnizität und Kultur oder der Theoretiker Homi K. Bhabha mit seinem Konzept von Hybridität den akademischen Diskurs. Auf beide wird im weiteren Verlauf der vorliegenden Arbeit noch näher eingegangen.

Es lässt sich also ein Trend nachverfolgen, der den Begriff der Diaspora seit den 1960er Jahren in stärkere konzeptuelle Nähe zu Begriffen wie Postkolonialismus, Transnationalismus und Migration rückte. Die sich daraus entwickelnde und als paradigmatisch geltende Definition von Diaspora ist dabei jene des Politikwissenschaftlers William Safran:

1) they [expatriate minority communities], or their ancestors, have been dispersed from a specific original ,center ${ }^{6}$ to two or more ,peripheral', or foreign, regions; 2) they retain a collective memory, vision, or myth, about their original homeland - its physical location, history, and achievements; 3) they believe that they are not - or cannot be - fully accepted by their host society and therefore feel partly alienated and insulated from it; 4) they regard their ances- 
tral homeland as their true, ideal home and as the place to which they or their descendants would (or should) eventually return - when conditions are appropriate; 5) they believe that they should, collectively be committed to the maintenance or restoration of their original homeland and to its safety and prosperity; and 6) they continue to relate, personally or vicariously, to that homeland in one way or another, and their ethnocommunal consciousness and solidarity are importantly defined by the existence of such a relationship. (83-84)

Gestützt auf Arbeiten des Politikwissenschaftlers Walker Connor, geht Safran in seinem Sammelbandbeitrag „Diasporas in Modern Societies: Myths of Homeland and Return“ in einem ersten Schritt dem etymologischen Ursprung des Begriffes nach und geht somit von der Bedeutung der geographischen Zerstreuung aus. Interessanterweise verläuft diese Bewegung oft quer zu vorherrschenden (geopolitischen) Semantiken von Zentrum und Peripherie. Maßgeblich für die von William Safran vorgeschlagene Definition ist zweitens der Ursprungsort, denn seiner Meinung nach ist Diaspora durch eine kollektive Erinnerung an diesen Ursprungsort gekennzeichnet. Drittens ist die Identifikation mit dem neuen fremden Ort nie ganz vollzogen, ein Gefühl der Fremdheit bleibt. Infolgedessen ist viertens eine Diaspora immer vom stetigen Wunsch nach einer Rückkehr an den Ursprungsort geprägt.

Diese Haltung ist nicht zwingend. Der Rückkehrwunsch kann im Sinne des sojourning in Erfüllung gehen oder, wie im Falle eines Exils, eben nicht. Sojourning meint im Gegensatz zu Diaspora keinen permanenten, sondern einen temporären Aufenthalt in einem anderen Land als dem Herkunftsland sowie eine mögliche oder gar von Anfang an vorgesehene und nach einiger Zeit eintretende Rückkehr in dieses. ${ }^{19}$ So hatten beispielsweise viele Iraner_innen der ersten Migrationswelle den Plan, nach ihrem Studium in Europa oder den Vereinigten Staaten nach Iran zurückzukehren, viele taten dies Anfang der 1970er Jahre 
auch. Exil wiederum meint im ursprünglichen Wortsinn im Gegensatz zu Diaspora „Verbannung“ und schließt somit von vornherein eine Rückkehr an einen angestammten Ursprungsort aus. Bereits in der Antike wurde das Exil als politisches Mittel eingesetzt: Politisch Unliebsamen wurde oftmals die Wahl zwischen Tod und Exil gelassen. Das bestimmt berühmteste Beispiel hierfür aus der Antike ist jenes von Sokrates, dem die Wahl zwischen dem Exil und dem Schierlingsbecher gegeben wurde. Er entschied sich für Letzteres. Diese Nähe der Begriffe zeigt die tragische Endgültigkeit des Exils, welches sich somit sowohl vom ursprünglichen als auch vom heutigen Begriff der Diaspora unterscheidet. ${ }^{20}$

Auch Robin Cohen hebt in seiner Definition die (unausweichliche) Rückbindung an ein vermeintliches Heimatland hervor: „A member's adherence to a diasporic community is demonstrated by an acceptance of an inescapable link with their past migration history and a sense of co-ethnicity with others of a similar background“" (ix). Im Versuch, die Gemeinsamkeiten der verschiedenen Arten von Diaspora in einer Definition zusammenzufassen, entwirft der Soziologe Rainer Bauböck in seinem Sammelbandbeitrag „Cold Constellations and Hot Identities: Political Theory Questions about Transnationalism and Diaspora“ gut zwanzig Jahre nach Robin Cohen ganz ähnliche Merkmale für Diaspora wie William Safran. Das erste Merkmal sei die Zerstreuung, das heißt in der Regel eine über Land-, Wasser- oder Luftwege verlaufende Form der Auswanderung aus einem angestammten Siedlungsgebiet und die Verteilung der betroffenen Personen über viele verschiedene Zielgebiete. Das zweite Merkmal sei Kontinuität bei der Bildung einer kollektiven Identität, die über Generationen außerhalb des ursprünglichen Herkunftslandes reproduziert wird. Das dritte Merkmal sei jenes der Verbindungen zwischen den verstreuten Gruppen, die sich in verschiedenen Territorien niederlassen und durch gemeinsame Erinnerungen Zugehörig- 
keiten herstellen. Das vierte Merkmal definiere Diaspora nicht nur in der Beschwörung von Vergangenheit, sondern auch in der Projektion in die Zukunft, einer Zukunft, die in dem Land liegt, wo die Migrant_innen herkommen (Bauböck 314). All diesen Ansätzen gemein ist eine lineare Direktionalität, die von einem (geographischen) Ort zu einem anderen führt und ethnische Entitäten entlang nationaler Bezugspunkte definiert und den Rückkehrgedanken hochhält.

Der Rückkehrgedanke allein, so wird in der vorliegenden Arbeit zu zeigen sein, wird dem Wandel innerhalb der Diaspora immer weniger gerecht und nimmt zunehmend eine untergeordnete Rolle ein. Khachig Tölölyan seinerseits verabschiedet sich nicht gänzlich von dem Gedanken an eine Rückkehr, nimmt jedoch bereits eine Differenzierung vor, die das Spannungsverhältnis zwischen dem Abgrenzen gegen und dem Annehmen von verschiedenen Elementen aufzeigt:

In my view, a collection of transnational migrants becomes a diaspora when its members develop some familial, cultural and social distance from their nation yet continue to care deeply about it not just on grounds of kinship and filiation, but by commitment to certain chosen affiliations. (11)

Dies ist unter anderem vor dem Hintergrund politischer Entwicklungen im Zeitalter der Globalisierung zu sehen, in der immer mehr Staaten ihre Auswanderer bewusst als Diaspora bezeichnen, und zwar in der Absicht, aus politischen, kulturellen und wirtschaftlichen Gründen die Loyalität dieser Menschen zu erhalten und zu mobilisieren. Zu den politischen Motiven gehört die Hoffnung, die Politik der Ankunftsländer über die Migrant_innen beeinflussen zu können. Zu den kulturellen Gründen zählt etwa die Erhöhung des internationalen Prestiges. Wirtschaftliche Gründe - und diese stehen oft im Vordergrund - sind, dass der Herkunftsstaat Emigrant_innen als Wirtschaftsfaktor entdeckt, vor allem ihre Rück- 
überweisungen und manchmal auch ihr Know-how. Sie werden aufgefordert, zur Entwicklung des Herkunftslandes beizutragen, indem sie ihr Geld oder ihre im Ausland erworbenen Qualifikationen dort investieren. Ein frühes Beispiel ist Indien, dessen weltweite Diaspora zunächst im Begriff der Overseas Indians und später in dem der Non-residential Indians (NRI) zusammengefasst wurde. Die Betonung liegt hierbei immer auf „Indians“, das derzeitige Aufenthaltsland in der Diaspora ist dabei sekundär. Eine ähnliche Entwicklung gibt es auch für Iran, welches den High Council of Iranian Affairs Abroad einrichtete. Khachig Tölölyan meint ferner:

He or she is a diasporic because of a set of cumulative decisions to continue to remain bi- or multi-local, to care about others in diaspora with whom he or she shares an ethnodiasporic origin, and also to care in some manner about the well-being of the homeland of the ancestors. (11)

Die Entwicklung ist interessant, da der Begriff der Diaspora etymologisch ja die Bedeutung von Zerstreuung, also einer Bewegung von einem Ort weg und nicht einer Rückkehr-Bewegung, zugeschrieben wird. Dass das Wort nicht nur den vermeintlichen Rückkehrwunsch der in der Diaspora Lebenden beschreibt, sondern auch von offizieller (Heimatland-)Seite im Sinne einer positiven Rückkoppelung verwendet wird, ist bezeichnend für den Wandel, den der Begriff durchgemacht hat.

Dieser Wandel von einer negativen Konnotation einer spezifischen Form der Zerstreuung (der jüdischen Diaspora) zu einem flexiblen und positiv besetzten Konzept macht den Begriff Diaspora zu einem wichtigen Konzept. Die Breite des Begriffes verwässere, so der Soziologe Rogers Brubaker in seinem Zeitschriftenaufsatz „The ,Diaspora“ Diaspora“, dessen Bedeutung jedoch zuneh- 
mend, und auch Stéphane Dufoix kritisiert: „In the space of about fifteen years, ,diaspora' has evolved into an allpurpose word used to describe a growing number of populations“ (30). Die Philosophin und Publizistin Isolde Charim wiederum sieht das in der Einleitung zu ihrem Sammelband Lebensmodell Diaspora genau umgekehrt: „Die damit einhergehende Schwammigkeit ist aber auch erhellend: Diese Vermehrung ist eine produktive Uneindeutigkeit. Sie macht den Begriff ,Diaspora‘ zum Symptom einer Entwicklung“ (Charim und Auer Borea 12). Diese Entwicklung schlägt sich nicht nur gesellschaftlich, sondern vor allem auch in einem gesteigerten wissenschaftlichen Interesse nieder, welches nicht zuletzt die Gründung der Diaspora Studies im angelsächsischen Raum hervorbrachte. Die anfangs erwähnte Fachzeitschrift Diaspora: A Journal of Transnational Studies sowie das Oxford Diaspora Programme: Exploring Migrants Networks and Experiences (2011-15) und Diasporas, Migration and Identities Programme ${ }^{21}$ seien hier als einige von vielen Forschungsprojekten und -publikationen genannt, welche in den letzten Jahren die Erforschung von Diaspora zum Schwerpunkt hatten.

Ich schließe mich der von Isolde Charim postulierten „erhellenden Schwammigkeit“ an und verstehe Diaspora als offenen und flexiblen Begriff. Dadurch eignet er sich für die Beschreibung kultureller wie medialer Prozesse und Praktiken dahingehend, als dass seine Fluidität die Analyse solcher Formen zulässt, die sich konkreten Zuschreibungen entziehen und durch Vielförmigkeit in Narration, Ästhetik und Stil bestechen. Im Folgenden diskutiere ich unterschiedliche Positionen, die das Diasporische durch und in Medien theoretisch wie methodisch zu fassen suchen. Ziel ist es, der eingangs gestellten Frage nachzugehen, was Diasporafilm ist oder eben auch nicht ist; wie er zur Beantwortung der Frage nach dem, was zeitgenössischer Film sein kann und darf, beiträgt; und wie er das generelle Verhältnis zwischen Raum und Film neu befragt. 


\subsection{Von den Diasporamedien zum Medienraum Diaspora}

Im Zusammenhang mit Diaspora nimmt die Forschung zu Medien vornehmlich die Produktion und Rezeption von Medien in der Diaspora, kurz: die medialen Praktiken in der Diaspora, in Augenschein. Herausgearbeitet wird in diesen empiriegeleiteten, sozial- und kommunikationswissenschaftlich orientierten Forschungen das gesteigerte Medieninteresse von in der Diaspora lebenden Menschen im Hinblick auf Mediennutzung und -aneignung. Der Publizist und Islamwissenschaftler Karim H. Karim vertritt in seinem Sammelbandbeitrag „Diaspora and Media" die Meinung, die Zerstreuung von Menschen würde diese dazu antreiben, verstärkt nach Möglichkeiten von Verbindungen zu suchen, und Medien würden dabei solche Verbindungsmöglichkeiten bieten: „The dispersed nature of settlement patterns has encouraged immigrants to adopt cutting-edge media technologies in order to develop links between their fellows, who are spread in several locations“ (162). Er stützt sich dabei auf die Theorien von Robert E. Park, wonach diese Suche durch die folgenden drei Ziele motiviert ist: Integration in größere gesellschaftliche Kontexte $\mathrm{zu}$ gewährleisten, kulturellen Zusammenhalt zu stärken und ethnische Kohäsion zu fördern (,The Immigrant Press").

In Ländern mit historisch gewachsenen großen Diasporaformationen wie der indischen Diaspora in Großbritannien, der maghrebinischen Diaspora in Frankreich oder der türkischen Diaspora in Deutschland und Österreich sind Printmedien auf Indisch, Arabisch oder Türkisch gang und gäbe. Form und Qualität variieren dabei von staatlich-finanzierten und regelmäßig erscheinenden bis hin zu privat-finanzierten und kurzlebigen Zeitschriften. Für Rundfunksendungen waren die in der Diaspora Lebenden in erster Linie auf die staatlichen Rundfunkstationen in den jeweiligen Ländern angewiesen, die ihnen zumeist (wenig 
attraktive) Sendeplätze und -slots zur Verfügung stellten. Die Schaffung eigener privater Rundfunksender und offener Kanäle ${ }^{22}$ boten Alternativen dazu und erreichten zumeist eine höhere Einschaltquote. Die seit dem Beginn des Jahrtausends verstärkte Nutzung des Internets und der sozialen Medien (Blogs, Facebook, Twitter, Instagram) erhöht ebenfalls sowohl Produzenten- als auch Rezipientenzahlen.

Andreas Hepp, Cigdem Bozdag und Laura Suna unterscheiden in ihrer sozialwissenschaftlichen und empirisch geleiteten Forschung zwischen drei verschiedenen Arten von in einer Diaspora lebenden Menschen, die sie allesamt unter dem Begriff „mediale Migranten“ zusammenfassen: „Herkunftsorientierte“ prägt demnach ein Zugehörigkeitsgefühl zu einem realen oder imaginierten Ursprungsort. Die daraus entstehende „Herkunftsvernetzung“ würde sich sowohl durch einen starken medialen Austausch mit Menschen in der gleichen Situation als auch durch einen starken medialen Austausch mit Menschen im Herkunftsland kennzeichnen. „Ethnoorientierte“ charakterisiere weniger die Abwesenheit eines eindeutigen Zugehörigkeitsgefühles, sondern präge die Aushandlung zwischen dem Herkunftsland und der Ankunftsgesellschaft. Daraus ergäbe sich die „bikulturelle Vernetzung“, die einen medialen Austausch sowohl lokal als auch translokal befördere. „Weltorientierte“ präge ein Zugehörigkeitsgefühl, welches über nationale und kulturelle Zuschreibungen hinausgehe. Die daraus entstehende „transkulturelle Vernetzung“ sei durch einen medialen Austausch über nationale und kulturelle Grenzen hinweg gekennzeichnet (69-71). Zugehörigkeitsgefühle und mediale Vernetzungsstrategien würden sich in dieser Konstellation immer wechselseitig bedingen:

Die Herkunftsvernetzung verstärkt die Artikulation einer herkunftsorientierten kulturellen Identität und damit wiede- 
rum eine Ausrichtung auf ein entsprechendes Kommunikationsnetzwerk. Eine bikulturelle Vernetzung verstärkt die Artikulation einer doppelten kulturellen Zugehörigkeit und damit wiederum eine Orientierung auf ein Kommunikationsnetzwerk zwischen Herkunfts- und Migrationsland. Eine transkulturelle Vernetzung verstärkt die Artikulation einer europäischen beziehungsweise globalen Zugehörigkeit und so eine Fokussierung auf ein weit reichendes transnationales Kommunikationsnetzwerk. (72)

In Anlehnung an das Konzept der „Ethnomedien“ der Bildungswissenschaftlerin Sonia Weber-Menges, das den Akzent auf Produzent_innen und Rezipient_innen legt, sowie jenes der ethnic media der Kommunikationswissenschaftlerin Isabel Awad, das Selbstrepräsentationen in den Fokus rückt, und das Konzept der diasporic media der Medienwissenschaftlerin Myria Georgiou, das die Adressierung in den Vordergrund stellt, schlagen Hepp, Bozdag und Suna folgende Definition von Diasporamedien vor:

Diasporamedien [bezeichnen solche Medien], die von Migrantinnen und Migranten produziert werden, migrationsspezifische Inhalte verhandeln und von diesen selbst angeeignet werden. Diasporamedien sind also diejenigen Medien, die sich im Zentrum des Gesamtkreislaufs der diasporischen Medienkultur artikulieren. (124; Hervorhebung im Original)

Diasporamedien bezeichnen in dieser Definition staatliche Rundfunksendungen und Printmedien ergänzende Medien, die es ermöglichen, eine sonst unterrepräsentierte Vielfalt darzustellen. Hepp, Bozdag und Suna meinen sogar, „Diasporamedien haben das Potenzial, [...] ,Lücken“ der Medienlandschaften von Migrationsländern zu füllen“ (125). Karim H. Karim sieht die verstärkte Nutzung des Internets in einer ähnlichen Stoßrichtung: „A primary motivation for migrant communities to go online seems to be survival in the face of the overwhelming 
output of dominant cultures“ („Diasporas and Media“ 165). Und auch Robert Cohen spricht der Diaspora eine erhöhte Mediensensibilität zu: „It is perhaps because of this need to be sensitive to the currents around them, that, in addition to their achievements in trade and finance, diaspora groups are typically overrepresented in the arts, in the cinema and in the media and entertainment industries“ (170). All diesen Ansätzen gemein ist die Nähe zu medienwissenschaftlichen Theorien und Diskursen rund um Partizipationskulturen.

Das Konzept der Partizipationskultur, welches sich aus den angelsächsischen Cultural Studies herausgebildet hat, steht dem Konzept der Konsumkultur gegenüber und meint den Wechsel von passiven Rezipient_innen zu aktiven Nutzer_innen. Im Zusammenhang mit Medien geht es um den Wechsel von Medienrezipient_innen zu Medienproduzent_innen und -distributor_innen, die somit zu Akteur_innen werden. Die Medienwissenschaftler Henry Jenkins, Sam Ford und Joshua Green sehen diesen Wandel in den neuesten Möglichkeiten der medialen Verbreitung, des Teilens und der Zirkulation, in dem, was sie spreadable media nennen:

This shift from distribution to circulation signals a movement toward a more participatory model of culture, one which sees the public not as simply consumers of preconstructed messages but as people who are shaping, sharing, reframing, and remixing media content in ways which might not have been previously imagined. (2)

Spreadable media beinhaltet nicht nur die Frage, wie geteilt wird, sondern vor allem auch, warum geteilt wird. Das allgegenwärtige Teilen von Inhalten auf sozialen Plattformen wie Facebook, Twitter, Instagram, YouTube, Tumblr, Flickr, Wikipedia et cetera wird hierbei nicht nur als soziale - wie in den Studien von Hepp, Bozdag und Suna -, sondern vor allem auch als kulturelle Praxis verstanden. Dem Teilen selbst kommt hierbei das Moment sowohl der techni- 
schen Möglichkeit als auch der kulturellen Praxis zu. Der Ethnologe Arjun Appadurai entwickelte dazu 1996 mit seinem Konzept der mediascapes ein viel beachtetes Modell:

What is most important about these mediascapes is that they provide (especially in their television, film, and cassettes forms) large and complex repertoires of images, narratives, and ethnoscapes to viewers throughout the world $[\ldots]$, and what they offer to those who experience and transform them is a series of elements (such as characters, plots, and textual forms) out of which scripts can be formed of imagined lives, their own as well as those of others living in other places. (Modernity at Large 35)

Der doppelte Bedeutungshorizont, der einerseits Diversifikation über vereinfachte Produktions- und Distributionskanäle erklärt sowie andererseits die Distribution und Zirkulation der durch Print, TV- und Film produzierten Bilder und Narrative meint, verdeutlicht die Komplexität der globalen Medienlandschaft. Sowohl in Appadurais Konzept, als auch in den Konzepten, die Medien als Verbindungs(Karim, „Diasporas and Media“) und/oder Vernetzungsmöglichkeiten (Hepp, Bozdag und Suna) für die Diaspora sehen, schwingt immer eine positive Haltung und die Hoffnung mit, räumliche und kulturelle Grenzen durch Medien zu überwinden. Jenkins, Ford und Green folgen diesen Hoffnungsansätzen nur mit Vorbehalt und räumen dem medialen Austausch auch eine Kehrseite ein: „Exchanges $[\ldots]$ may strengthen cultural ties but may also force them to confront what is distinctive about their different cultural locations and histories" (278). Medien würden demnach oft auch ein hohes Potenzial der Differenzerzeugung zwischen den in der Diaspora lebenden und denjenigen am Ursprungsort in sich bergen, wobei Differenz durchaus als kreative Triebfeder gesehen werden kann: 
Yet a growing number of diasporic communities are tapping into the potential to use new media platforms to forge stronger social networks that link the old world and the new on an ongoing basis. [...] The opposite is often the case, with the flow of media content across national borders serving as a reminder of the differences within immigrant communities, of the gaps between the lived experience of those who remain in the motherland and the perceptions of those who have sought a nostalgic return after extended stays overseas. (278)

All diesen Ansätzen ist zugutezuhalten, dass sie das Ziel verfolgen, Diaspora als globales Phänomen und aktives Element innerhalb von Medienlandschaften zu betrachten und sie damit von der Peripherie ins Zentrum zu rücken. Ausgelassen wird hierbei jedoch die Tatsache, dass Medien nicht nur produziert werden, sondern auch produzieren. Film kommt hierbei im Gegensatz zu neuen und sozialen Medien eine besondere Rolle zu. Diasporafilm bedeutet nicht nur Diaspora im Film, vielmehr sind Diaspora und Film miteinander verflochten.

Die basale Annahme ist zunächst, dass Film nach Literatur, Musik, Photographie, bildender und darstellender Kunst eines der frühesten modernen beziehungsweise apparativen Medien ist, das von in der Diaspora lebenden Menschen produziert und rezipiert wurde, wie Filmwissenschaftler Thomas Elsaesser folgendermaßen formuliert: „Cinema seems to have become the most prominent medium of self-representation and symbolic action that the hyphenated citizens of Europe's nation states have made their own“ (119). Die Forschungsthemen dazu reichen von europäischen Exilant_innen in Hollywood (Elsaesser) über migrantische Filme in Europa (Berghahn und Sternberg) bis hin zu indischen, lateinamerikanischen und afrikanischen Filmen weltweit (Foerster, Perneczky, Tietke und Valenti). Seit den 1990er Jahren allerdings ist das Interesse in den Filmwissenschaften an Diasporafilmen als globales - und nicht nur ethnisches und migrantisches - Phänomen gestiegen: „The collective experience of dis- 
placement and dispersion inherent in the concept of diaspora is the most important creative impetus behind a variety of cinemas“ (Berghahn 157). Im Versuch, eine Definition von „Diasporafilm“ zu finden, wird schnell klar, dass es keine abschließende Definition für dieses komplexe Filmschaffen gibt. Viele Ansätze resultieren in Formen von Homogenisierung, die den Spezifika dieses politisch, kulturell und sozioökonomisch relevanten Filmschaffens nicht gerecht werden. Daher möchte ich nachstehend verschiedene filmtheoretische Herangehensweisen, die jeweils andere Fokusse legen und nationale (exilic cinema; migrant cinema), sozio-politische (third cinema; third world cinema), ökonomische (world cinema), transnationale (transnational cinema; cinema of transvergence) oder ästhetisch-stilistische (accented cinema; intercultural/haptic cinema) Aspekte beleuchten, diskutieren, um so zu einer Eingrenzung des Begriffes zu gelangen.

Eine erste Nuancierung nimmt Hamid Naficy in der Unterscheidung zwischen Exil und Diaspora vor:

Unlike the exiles whose identity entails a vertical and primary relationship with their homeland, diasporic consciousness is horizontal and multisited, involving not only the homeland but also the compatriot communities elsewhere. As a result, plurality, multiplicity, and hybridity are structured in dominance among the diasporans, while among the political exiles, binarism and duality rule. ( $A n$ Accented Cinema 14)

Dies bringt ihn zur Unterscheidung zwischen exilic cinema und diasporic cinema:

Diasporized filmmakers tend to be centered less than the exiled filmmakers on a cathected relationship with a single homeland and on a claim that they represent it and its people. As a result, their works are expressed less in the narratives of retrospection, loss, and absence or in strictly parti- 
sanal political terms. Their films are accented more fully than those of the exiles by the plurality and performativity of identity. In short, while binarism and subtraction in particular accent exilic films, diasporic films are accented more by multiplicity and addition. (14-15)

Exilic cinema sei demnach erstens von Binaritäten und partikularen Interessen durchzogen, wohingegen diasporic cinema die viel flexiblere Kategorie bilden würde, um Pluralität und Identität verhandeln und dadurch vollauf als accented bezeichnet werden zu können. Sein Konzept des accented cinema entspringt somit dem Akzent, welchen Filmschaffende auf ihre Filme legen, der nicht durch Sprache, sondern durch Zerstreuung und Handwerklichkeit begründet ist: „The accent emanates not so much from the accented speech of the diegetic characters as from the displacement of the filmmakers and their artisanal production modes“ (Naficy, An Accented Cinema 4). Es bezeichnet ein Filmschaffen, welches aus einem Dazwischen entspringt und Binaritäten zugunsten von Simultaneitäten aufweicht:

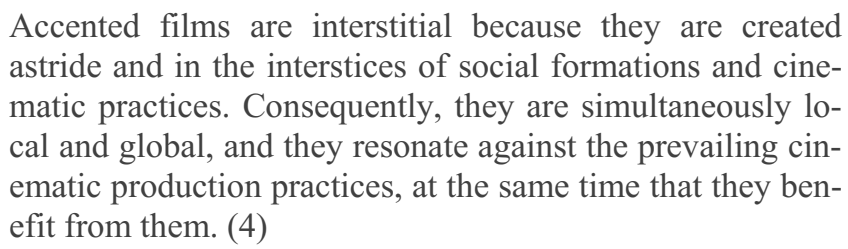

Dem Diasporafilm kommt dabei nicht nur die Funktion des Aufweichens und Sichtbarmachens zu, sondern es geht ihm vor allem um Vermittlung und um die Ermöglichung eines Dialoges: „Accented films are in dialogue with the home and host societies and their respective national cinemas, as well as with audiences, many of whom are similarly transnational, whose desires, aspirations, and fears they express“ (6). Dadurch konzipiert Naficy den Diasporafilm nicht als bloße Mischform hybrider Ästhetiken und Stile, sondern weist ihm eine Vermitt- 
lungsfunktion zu. Des Weiteren charakterisiert er accented cinema durch das Zusammenspiel zwischen Ästhetik und Politik: „Open-form and closed-form visual style; fragmented, multilingual, epistolary, self-reflexive, and critically juxtaposed narrative structure“ (4). Accented cinema sieht er nicht losgelöst von Politik, sondern er sieht Politik im Gegenteil als maßgebend für den Stil des accented cinema: ,the accented style continually grapples with the politicized immediacy of the films and with their collective enunciation and reception - that is, with the manner in which politics infuses all aspects of their existence“ (6). $\mathrm{Zu}$ guter Letzt hebt er accented cinema als Filmschaffen hervor, dem die Darbietung und Aushandlung von Identität innewohnen: „Each accented film may be thought of as a performance of its author's identity“ (6).

Mein Ansatz setzt auf einer anderen Ebene an. Politik und Identität sind zweifellos wichtige Topoi des Diasporafilmes, dieser zeichnet sich jedoch nicht allein durch eine Vermittlungsfunktion aus. Die Charakterisierung über eine Anbindung an das Herkunftsland als Fortführung eines nationalen Filmschaffens außerhalb bestehender Staatsgrenzen wird diesem komplexen und eigenständigen Filmschaffen nicht gerecht. Die Konstitution diasporischer Räume ist medial bedingt, nicht nur vermittelt. Diasporaraum ist immer auch Medienraum.

Eine andere Nuancierung ist jene zwischen migrant cinema und diasporic cinema, welche die Filmwissenschaftlerinnen Daniela Berghahn und Claudia Sternberg in der Einleitung zu ihrem Sammelband European Cinema in Motion: Migrant and Diasporic Film in Contemporary Europe folgendermaßen formulieren:

,Migrant" (,first-generation') film-makers have themselves been part of a migratory movement and departed from a place of birth or residence in search of better economic conditions or a more secure and stable socio-political environment. ,Diasporic ' film-makers are typically of the sec- 
ond, third or a later generation. They were born or raised in a diasporic setting and have no, or only a very remote, firsthand experience of migration. They are, however, connected to their family's migration and history of relocation or dispersal through kinship networks, family narratives, cultural practice, language, artefacts, etc. („Locating“ 16)

Migrant cinema unterscheidet sich von diasporic cinema im Wesentlichen durch die Herkunft der Filmschaffenden, welche aus erster Generation andere Themen in den Vordergrund stellen würden als jene aus zweiter beziehungsweise dritter Generation. ${ }^{23}$ Beiden gemein ist die Beschäftigung mit Identitätskonstruktion und die Infragestellung von Masternarrativen: „Migrant and diasporic cinema addresses questions of identity formation, challenges national and ethnocentric myths, and revisits and revises traditional historical narratives" (Berghahn und Sternberg, „Introduction“ 2). Diese temporale Linearität, Diaspora entlang chronologischer Bezugspunkte und Lebensläufe zu konzipieren, führt in die Richtung einer Definition, die stärker individualisierte kulturelle Praktiken - die sich in Narration und Ästhetik der Filme wiederfinden - in den Blick nimmt. Gleichzeitig spielt das Thema der Migration für viele Migrant_innen im Zeitalter des Postmigrantischen selbst keine Rolle mehr. Der Diasporafilm ist also gleichwohl losgelöst von Migrationsthematiken zu sehen ${ }^{24}$, da, wie ich es in dieser Arbeit postuliere, eine Abkehr von essentialistischen und ethnozentristischen Sichtweisen auf den Diasporafilm stattgefunden hat.

Wenn nun also weder nationales noch migrantisches Filmschaffen befriedigende Anschlüsse für den Diasporafilm bieten, so vermag dies vielleicht das Konzept des transnational cinema, welches in der Definition der Filmwissenschaftler_innen Elizabeth Ezra und Terry Rowden in der Einleitung zu ihrem Sammelband Transnational Cinema: The Film Reader nicht nur das Überwin- 
den nationaler Zuschreibungen im Zeitalter von vernetzten Strömen bedeutet, sondern immer auch Gegenpositionen mitdenkt: „Transnational comprises both globalization - in cinematic terms, Hollywood's domination of world film markets - and the counter-hegemonic responses of filmmakers from former colonial and Third World countries“ (1). In einem weiteren Schritt rücken Ezra und Rowden den Begriff in die Nähe zu jenen der Mobilität und Zerstreuung - beides auch Merkmale von Diaspora -, wenn sie sehr allgemein formuliert schreiben:

More often than not, transnational cinema's narrative dynamic is generated by a sense of loss. The lingering appeal of notions of cultural authenticity and normative ideas of ,home' prompts filmmakers to explore the ways in which physical mobility across borders necessarily entails significant emotional conflict and psychological adjustment. [...] As a figure within cinematic productions, the image of the displaced person grounds the transnational both thematically and in terms of global awareness. (7)

Auch wenn Diaspora in ihrer grundlegenden Definition die Zerstreuung von Menschen über verschiedene nationale Grenzen bedeutet, so möchte ich mit den Kulturwissenschaftlerinnen Jana Braziel und Anita Mannur argumentieren, dass der Begriff nicht vorschnell mit jenem der Transnationalität gleichzusetzen ist:

Transnationalism may be defined as the flow of people, ideas, goods and capital across national territories in a way that undermines nationality and nationalism as discrete categories of identification, economic organization, and political constitution. We differentiate diaspora from transnationalism, however, in that diaspora refers specifically to the movement - forced or voluntary - of people from one or more nation states to another. [...] While diaspora may be regarded as concomitant with transnationalism, or even in some cases consequent of transnationalist forces, it may not be reduced to such macroeconomic and technological 
flows. It remains, above all, a human phenomenon - lived and experienced. (Theorizing Diaspora 8)

Diaspora bezieht sich, so möchte ich diesem Ansatz folgend argumentieren, im Gegensatz zur ökonomischen und politischen Transnationalität auf die Bewegung, Mobilität und Erfahrung von Menschen. Eine klare Definition, was unter transnational cinema genau $\mathrm{zu}$ fassen ist, bleibt in den meisten Theorien aus. Filmwissenschaftler Will Higbee sieht das Problem vor allem in der fehlenden soziokulturellen und politischen Kontextualisierung des Begriffes:

One of the characteristics of transnational cinema is, precisely, that the images and representations offered by these filmmakers can potentially circulate more freely than ever before in a multitude of formats (film, DVD, Internet, satellite TV, mobile phones), their production nonetheless emanates from a clear socio-cultural and political context that also needs to be identified. (84)

Ergo meint Diasporafilm nicht dasselbe wie transnational cinema, auch wenn eine Nähe der beiden Konzepte zueinander feststellbar ist: „Transnational cinema appears to be concerned with the relationship between globalization and diaspora“ (Higbee 84). Vereinfachte Distributionskanäle, wie auch im Konzept der spreadable media angelegt, sind nur ein Merkmal für transnational cinema, die Produktionskanäle bedürfen einer näheren Definition. Der Medienwissenschaftler Andreas Jahn-Sudmann spricht von transnational cinema als einem „umbrella term“ (22), und auch Filmwissenschaftlerin Deborah Shaw kritisiert an den einschlägigen Theorien zu transnational cinema die allzu große Breite des Begriffes: „Transnational cinema“ as a catch-all is inadequate to deal with the complexities of categorising both actual films and industrial practices“" (48), und weiter: „It [transnational cinema] does not define an aesthetic approach, a movement of filmmakers, any specific national grouping, and neither does it 
separate out areas of study“ (51). Sie schlägt daher fünfzehn Analysekategorien vor, die bei einer Eingrenzung des Begriffes helfen sollen:

- transnational modes of production, distribution and exhibition

- transnational modes of narration

- cinema of globalization

- films with multiple locations

- $\quad$ exilic and diasporic filmmaking

- film and cultural exchange

- transnational influences

- transnational critical approaches

- transnational viewing practices

- transregional/transcommunity films

- transnational stars

- transnational directors

- the ethics of transnationalism

- transnational collaborative networks

- national films (52)

Deborah Shaw mahnt damit zur Genauigkeit und Spezifizierung im Umgang mit komplexen filmischen Formen: „The above categories alert us to the importance of specificity in any discussion of ,transnational cinema“" (Shaw 65).

Will Higbee seinerseits schlägt gegenüber dem allzu dehnbaren Begriff transnational cinema das Konzept des cinema of transvergence vor:

Instead it [cinema of transvergence] proposes a clear understanding of the discontinuity, difference and imbalances of power that exist between various film-makers, film cultures and film industries as well as the elements of interconnectedness that may bind a film-maker to a given film culture or national identity at a given time. (87) 
Den von dem Architekten und Kunstwissenschaftler Marcos Novak entliehenen Begriff transvergence verwendet er dabei, um das Moment der kulturellen Differenz zu betonen:

In the context of national/transnational cinemas we might say that whereas a nationalist ideology might attempt to paper over the cracks of difference, transvergence, in a very postmodern way, aims to expose and foreground (celebrate even) such differences. (85)

Das Begriffspaar national/transnational würde Differenzen nur überspielen, transvergence hingegen würde Differenz herauskehren, ja sogar zelebrieren. Durch das Herausstreichen von Differenz als produktive kulturelle Triebfeder hat cinema of transvergence das Potenzial, jene Differenzen von Diasporaformationen wie das Gefälle zwischen Zentrum und Peripherie, die transnational cinema zwar aufzeigt, jedoch nicht überwindet, zusammenzudenken und auszuhandeln:

For these [postcolonial or diasporic cinemas] are cinemas that aim, precisely, to place supposedly marginal experiences at the center of the filmic text (both in terms of narrative and representation). [...] A cinema of transvergence can therefore negotiate a position that is both center and margin. (Higbee 86)

In diesem Sinne stellt sich für meine Definition des Diasporafilmes nicht die Frage nach der Kategorisierung als entweder „,national“ oder „transnational“, sondern es geht um die Aushandlung beider Pole, um ein Dazwischen verschiedener Nationen, transnationaler Bewegungen und Kulturen. Der Diasporafilm unterscheidet sich daher wesentlich vom transnational cinema, das als Überbegriff zu verstehen ist, um globale Distributions-, Produktions- und Rezeptionswege zusammen zu fassen. Dieser Überbegriff kann jedoch die Komplexität von 
Diasporafilm, als ein Filmschaffen nicht der Kon-, sondern der Transvergenz, in dem es um die Aushandlung von Differenz und kultureller Erfahrung geht, nicht gänzlich fassen.

Auch Konzepte rund um den Begriff des world cinema nehmen, wie transnational cinema, einen ähnlich ungenauen Bezug auf Diaspora: „Nowhere are the dilemmas of world cinema more apparent than in the vexed question of certain world cinemas' relation to diasporic communities“ (Elsaesser 510). In Anlehnung an die Begriffe der world music und world literature beschreibt der Begriff oftmals nicht-englischsprachige filmische Formen, die sich von dominanten Hollywood-Produktionen abheben wollen. Der Referenzpunkt ist dabei immer Hollywood selbst, der Vergleich damit und die Abgrenzung dagegen. Jedoch nicht allein die Binarität zwischen Hollywood und dem restlichen Filmschaffen der Welt wird hierbei verhandelt, sondern auch die damit verbundenen Binaritäten wie Modernität/Tradition, Zentrum/Peripherie, global/lokal et cetera. Die Kulturwissenschaftlerin Ella Shohat und der Filmwissenschaftler Robert Stam setzen diesen Dualismen, in einer Vermischung von third world und third cinema, den Begriff des third world cinema entgegen: „,Third World Cinema“, far from being a marginal appendage to First World cinema - Hollywood's ,poor relative“ -, actually produces most of the world's feature films“ (97). Eine Definition von world cinema als Filmschaffen, welches stärker durch ein Sowohl-alsauch (von Nationalem und Internationalem, kommerziellem Kino und Arthousekino et cetera) geprägt ist, könnte demnach laut Thomas Elsaesser folgendermaßen lauten: „One definition of world cinema would indeed see such films as part of the identity politics that has permeated both developed and developing nations“ (508). Filmwissenschaftlerin Lúcia Nagib hebt ihrerseits hervor: „Once 
the idea of a single centre is eliminated, nothing needs to be excluded from the world cinema map [...], a world made of interconnected cinemas“ (30).

Eingedenk dieser Ansätze kann der Begriff des world cinema in seinem Bestreben, Binaritäten und Dualismen zugunsten von einem Nebeneinander von Verflechtungen und Verschränkungen aufzuheben, durchaus für die Analyse von diasporischem Filmschaffen produktiv gemacht werden. Die positive Besetzung des Begriffes weist den Diasporafilm als Filmschaffen aus, das nicht mehr Minoritäten, marginalisierte Gruppen oder ethnische Minderheiten gegenüber einer Mehrheitsgesellschaft oder Hegemonialmacht wie Hollywood repräsentiert, vielmehr sind es die Filme - als Teil der Welt - selber, durch die neue Räume, an denen die Grenzen zwischen binären Zuschreibungen längst verschwommen sind, sichtbar werden: „World cinema is simply the cinema of the world. It has no centre. It is not the other, but it is us. It has no beginning and no end, but is a global process. World cinema, as the world itself, is circulation“ (Nagib 31). Dieser Ansatz geht von einer räumlichen Perspektive aus: Filmschaffen als Grenzen überwindendes, weltumspannendes Phänomen. Und so kann auch ein Begriff wie third cinema, der von den Filmschaffenden Fernando Solanas und Octavio Gettino in ihrem Manifest „Towards a Third Cinema“ bereits Ende der 1960er Jahre geprägt wurde, im Zusammenhang mit Diaspora wieder fruchtbar gemacht werden, wenn mensch das zeitgenössische politische Kino als eines von Raum und Erfahrung begreift: „Die interessanteren Strömungen des neuen politischen Kinos zeichnet dagegen ein Beharren auf der Textur partikularer Orte und Erfahrungen aus“ (Foerster, Perneczky, Tietke und Valenti 13). Insofern schließt world cinema als Sammelbegriff den Diasporafilm durchaus ein, allerdings nur in diesem spezifischen Teilaspekt. 
Andere Ansätze zum Diasporafilm heben in ihrer Suche nach einer Definition auf eben jene Textur, die Ästhetik, ab. Daniela Berghahn beschreibt diese als hybrides Nebeneinander von filmischen Stilen und Einflüssen: „Diasporic cinema is an aesthetically hybrid cinema that juxtaposes and fuses stylistic templates, generic conventions, narrative and musical traditions, languages and performance styles from more than one (film) culture“ (163). Die Film- und Islamwissenschaftlerin Laura U. Marks verfolgt in ihrer Monographie The Skin of the Film mit dem Konzept des intercultural cinema, ebenso wie der Kunsthistoriker Nicholas Mirzoeff mit seinem Entwurf der intervisuality und die Historikerin Kobena Mercer mit ihrer Vorstellung der dialogic imagination, einen ähnlichen Ansatz der ästhetischen Mischformen: „Intercultural cinema is characterized by experimental styles that attempt to represent the experience of living between two or more cultural regimes of knowledge“ (Marks 1). Ihr Fokus liegt dabei auf der Vermischung verschiedener kultureller Einflüsse, Erinnerungen und Erfahrungen: „Intercultural cinema draws from many cultural traditions, many ways of representing memory and experience, and synthesizes them with contemporary Western cinematic practices“ (1-2). „Interkulturell“ bezieht dabei, im Gegensatz $\mathrm{zu}$ „multikulturell“, nicht nur die Begegnung und Verschmelzung, sondern auch die Wissensproduktion verschiedener Kulturen mit ein:

,Intercultural' means that a work is not the property of any single culture, but mediates at least in two directions. It accounts for the encounter between different cultural organizations of knowledge, which is one of intercultural cinema's synthesis of new forms of expression. (6-7)

Laura U. Marks' Konzept des intercultural cinema ermöglicht, den Diasporafilm nicht entlang ethnischer Zugehörigkeiten von Minderheiten/Mehrheiten zu fassen, wie dies in Konzepten des cinéma beur, non-residential indian film, black 
cinema oder cine latino der Fall ist, sondern „cinema as a relation between cultures“ (7) - Film als Verhältnis, Beziehung oder auch Verbindung zwischen Kulturen zu verstehen. Damit reiht sich Marks nicht nur in die Theorien nichtessentialistischer Definitionen von Kultur ein, wie in den Cultural und Postcolonial Studies angelegt, sondern ermöglicht es meines Erachtens, und wie im Kapitel „Zwischenräume“ exemplarisch dargelegt wird, den Diasporafilm als Phänomen zu begreifen, welchem eine Scharnierfunktion zukommt.

In der Gesamtschau der verschiedenen hier skizzierten theoretischen Ansätze werden Medien aus meiner Sicht nicht nur genutzt, um, wie im Falle der Diasporamedien, räumlich(-geographische) Distanz zu überwinden, sondern es ist ihre ästhetische Nutzung, wie im Falle des Diasporafilmes, die neue Räume schafft und sichtbar macht. Dieser Aspekt ist zentral, denn Diasporafilm verhandelt nicht nur Räume innerhalb der filmischen Diegese, sondern eröffnet neue mediale Räume, durch die sich die Diaspora selbst verhandelt und verortet.

Die Medienwissenschaftlerin Brigitte Hipfl unterscheidet in diesem $\mathrm{Zu}$ sammenhang in ihrem Sammelbandbeitrag „Mediale Identitätsräume: Skizzen zu einem ,spatial turn“ in der Medien- und Kommunikationswissenschaft“" Medien entlang dreier Funktionen: Medien als „geopolitische Räume“, Medien als „,semiotische Räume“ und Medien als „Zwischen-Räume“. Besonders interessant im Hinblick auf Diaspora ist hier die dritte Funktion der Zwischen-Räume (16):

Das ,Zwischen' soll verdeutlichen, dass in der Interaktion mit Medien mehr passiert als bloß ein Einstieg der Rezipientinnen oder Userinnen in die von den Medien zur Verfügung gestellten mentalen Räume. Vielmehr entstehen dabei neue Räume, in denen je spezifische Identitäten der Nutzerinnen (re-)konstituiert werden. (17) 
Auf die Diaspora übertragen heißt das, dass die Mediennutzung beziehungsweise -aneignung nicht nur Verbindungen kreiert und Differenzen aufdeckt, sondern vor allem auch neue Medienräume schafft, in denen die Diaspora sich selbst verhandelt und rekonfiguriert. Es sind nicht länger physisch-territoriale Räume, die der kulturellen Identität der Diaspora dienen, vielmehr sind es symbolische und durch Medien geschaffene Räume: „Medienräume sind Räume ohne materielle Körper“ (Hipfl 25). Die Aufhebung des physisch-territorialen Raumbegriffes im spatial turn zugunsten eines relationalen Begriffes, dem ein Netzwerkgedanke innewohnt, welcher kulturelle und mediale Praktiken in den Vordergrund stellt, ist hierbei der Ausgangspunkt für meine Konzeption der Diaspora als Medienraum. Damit möchte ich nicht nur nach dem Wesen des filmischen Raumes, sondern auch nach seiner Medialität fragen. Der Diasporafilm weist differenziertere Ebenen des Raumes auf, da er es vermag, Verbindungen zwischen filmischen und nicht-filmischen Räumen herzustellen. Damit kann, dieser Prämisse folgend, der Zusammenhang zwischen Diaspora und Medien von Theorien der Mediennutzung und/oder -aneignung von in der Diaspora lebenden Menschen gelöst und im Hinblick auf die Medialität von Diaspora und Diaspora als Medienraum hin erweitert werden.

Diesem Medienraum ist eine eigene (filmische) Raumlogik eingeschrieben. Die Filmphilosophin Laura Frahm unterscheidet in ihrem Sammelbandbeitrag „Logiken der Transformation: Zum Raumwissen des Films“ „bewegte Räume“, „konstruierte Räume“ und „mediale Räume“ (272). Unter „bewegten Räumen“ versteht sie den filmischen Raum als in sich immer dynamischen Raum, der in Bewegung ist:

Filmische Räume sind Räume, die nicht mehr mit dem Verständnis eines grundsätzlich unbewegten, in sich geschlossenen Behälterraums zu vereinen sind. Sie sind vielmehr selbst in Bewegung; sie bilden genuin bewegte Räu- 
me heraus, die einer kontinuierlichen Transformation unterliegen. (272; Hervorhebung im Original)

„Konstruierte Räume“ sind sie deshalb, weil ihnen die Möglichkeit der Raumgenerierung immanent ist: „Sie sind konstruierte Räume, in denen potenziell jeder Anschluss und jede Raumfolge möglich ist und die zugleich als paradoxe Raumkonstruktionen in Erscheinung treten können.“ (272; Hervorhebung im Original).

In diesem Sinne

entziehen sich filmische Räume einer unmittelbaren Rückführung auf den materiellen Raum, oder präziser: Selbst wenn sie auf diesen zurückgeführt werden können, so geschieht dies allein im Durchgang durch eine filmische Transformation, die als solche im Film wiederum reflektiert wird, wodurch filmische Räume in ihrer dritten Eigenschaft als mediale Räume in Erscheinung treten. (272; Hervorhebung im Original)

Losgelöst vom materiellen Raum haben filmische Räume als „mediale Räume“ das Potenzial für Transformation und Veränderung. Laura Frahm weiter:

Dem Film wohnt eine spezifische Raumlogik inne; er birgt ein besonderes Raumwissen, das gleichermaßen in seiner inneren konzeptuellen Anlage begründet liegt, wie es sich nach außen hin als eigenes Raumgebungsverfahren artikuliert. (271)

Der Diasporafilm ist von dieser filmeigenen Raumlogik nicht ausgenommen, im Gegenteil, er verstärkt, vergrößert und akzentuiert den filmischen Raum als medialen Raum durch seine ihm eigenen ästhetischen Verfahren, auf die ich im Kapitel „Neue diasporafilmische Räume“ noch näher eingehen werde. 
Film verhandelt immer Räume. Mit Brigitte Hipfl und Laura Frahm möchte ich argumentieren, dass es sich bei Diasporafilmen um Filme handelt, die nicht nur außerhalb eines Ursprungsortes produziert und rezipiert werden - von Filmschaffenden, die meist autobiographische Inhalte darin verhandeln und oftmals damit eine politische Aussage verbinden -, sondern die auch eine erhöhte Medien- sowie Raumsensibilität aufweisen. Diese Medien- und Raumsensibilität ergibt sich nicht nur aus der Tatsache, dass sowohl Film als auch Diaspora in sich bereits räumliche Konzepte sind, sondern aus der Kombination und Wechselwirkung zwischen Diaspora und Film, die es ermöglicht, im Umkehrschluss auch Diaspora als Medienraum zu begreifen, der durch die Filme immer schon reflexiv mitbehandelt wird. In diesem Sinne verstehe ich Diasporafilm als eine offene Form, die sich nicht letztgültig bestimmen lässt, sondern vielmehr ein vielgestaltiges Konzept darstellt, das die Bedeutung der Kategorie Diaspora in unterschiedlichen Gesellschaftskonstellationen beschreibbar macht.

Der filmtheoretische Kontext, in welchem der Diasporafilm zu verorten ist, zeigt, dass dieser sich weniger über eine spezifische Ikonographie oder einzelne Themen definieren lässt, sondern über den sich stetig neu konstituierenden (filmischen) Raum. Genauer: Er zeichnet sich durch den diskursiven Raum aus, welcher durch sich verändernde filmische Räume mitkonstruiert wird. Denn wenn mensch im Anschluss an einen flexiblen medientheoretischen Begriff der Diaspora davon ausgeht, dass diese Filme Diasporaerfahrungen nicht nur repräsentieren, sondern zugleich Diaspora als Medienraum präsentieren, dann kann geschlussfolgert werden, dass die Art und Weise, wie Diaspora inszeniert wird, unmittelbar die filmischen/medialen Räume mitbestimmt. Dort, wo sich die Rede um Diaspora als Raum mit dem Filmraum in die wissenschaftlichen Theorien der Diaspora Studies einschreibt, verknüpft sie sich häufig mit ganz unterschiedlichen Anliegen. Dann stellt sich die Frage, inwiefern die sozio-historische Kate- 
gorie „iranische Diaspora“ als eine spezifische filmische Ausdrucksweise konzipierbar ist. Diaspora und Raum sind unwiderruflich miteinander verbunden. Nicht als Genre, nicht als Motiv oder Handlungselement ist Diaspora in diesem Zusammenhang auf den filmischen Raum zu beziehen, sondern vielmehr als Vergrößerungsglas, das Film in seiner Theorie, Geschichte und Ästhetik reflektiert. Inwiefern spezifisch der iranische Diasporafilm in seiner Heterogenität hinsichtlich der Transformationsprozesse, denen er unterliegt, zu fassen ist, möchte ich im Folgenden durch eine raum- und kulturtheoretische Perspektivierung der iranischen Diaspora selbst darlegen.

Open Access Dieses Kapitel wird unter der Creative Commons Namensnennung 4.0 International Lizenz (http://creativecommons.org/licenses/by/4.0/deed.de) veröffentlicht, welche die Nutzung, Vervielfältigung, Bearbeitung, Verbreitung und Wiedergabe in jeglichem Medium und Format erlaubt, sofern Sie den/die ursprünglichen Autor(en) und die Quelle ordnungsgemäß nennen, einen Link zur Creative Commons Lizenz beifügen und angeben, ob Änderungen vorgenommen wurden.

Die in diesem Kapitel enthaltenen Bilder und sonstiges Drittmaterial unterliegen ebenfalls der genannten Creative Commons Lizenz, sofern sich aus der Abbildungslegende nichts anderes ergibt. Sofern das betreffende Material nicht unter der genannten Creative Commons Lizenz steht und die betreffende Handlung nicht nach gesetzlichen Vorschriften erlaubt ist, ist für die oben aufgeführten Weiterverwendungen des Materials die Einwilligung des jeweiligen Rechteinhabers einzuholen.

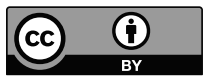

